\title{
Peri-Urban Growth into Natural Hazard-Prone Areas. Mapping Exposure Transformation of the Built Environment in Nairobi and Nyeri, Kenya from 1948 to Today
}

Alexander Fekete ( $\sim$ alexander.fekete@th-koeln.de )

TH Köln University of Applied Sciences https://orcid.org/0000-0002-8029-6774

\section{Research Article}

Keywords: Change detection, land-use change, transformation, urban sprawl, risk assessment, GIS

Posted Date: December 13th, 2021

DOI: https://doi.org/10.21203/rs.3.rs-1117045/v1

License: (c) (i) This work is licensed under a Creative Commons Attribution 4.0 International License. Read Full License 


\section{Abstract}

Kenya experiences massive urban growth, also into natural hazard-prone areas, exposing settlements and the natural environment to riverine and pluvial floods and other natural hazards. While Nairobi as the capital and principal city has been extensively analysed regarding urban growth and flood hazard in some central parts, awareness of growing periurban areas has not been studied as much. The results are of interest to other locations in Kenya and worldwide, too, since the current research and disaster risk practice focus is still too much on megacities and city centres. Therefore, the study compares urban growth into hazard areas in urban rims of Nairobi and Nyeri, Kenya. A change assessment from 1948 to 2020 is conducted by aerial images, declassified satellite images, and recent data. Urban growth rates are 10 to 20-fold, while growth into flood exposed areas ranges from 3 to 100-fold. This study reveals unused opportunities for expanding existing land-use change analysis back to the 1940s in data-scarce environments.

\section{Introduction}

Demands for risk monitoring and risk-informed decision-making are expressed by the Sendai Framework (United Nations 2015). Similarly, the needs for integrative assessments, including basic infrastructure, urban features and disaster risk, are expressed in the New Urban Agenda (UN/HABITAT 2017). However, while disaster risk studies have covered major cities and national capitals, studies on smaller cities or peri-urban areas are lacking widely (Birkmann et al. 2016).

Peri-urban areas are often among the fastest-growing urban areas when close to a major city or capital like Nairobi. Urban growth also expands the ratio of built-up areas potentially exposed to natural hazards such as floods or droughts. Monitoring of disaster risk needs to capture static pictures of risk and include the dynamics to better understand risk and resilience development and identify pathways to govern urban areas towards better resilience in coping with shocks and disasters (Simonovic and Peck 2013). This notion of the importance of dynamic risk assessments is expressed by recent research on aspects of the transformation of cities (Pelling et al. 2015), pathways in coping with climate change (Gibson et al. 2016), or transition (Solecki et al. 2017). However, this leads to a demand for data available for long periods to analyse changes.

Limitations of static risk assessments have long been acknowledged (King 2001), but few studies provide change assessments of disaster risk. This is often due to the lack of data for comparison or awareness about existing sources of data. While this is a challenge existing worldwide, availability and access to data are a major constraint for many countries in Africa (Osuteye et al. 2017). It seems paramount to improve data usability for risk assessments, and this paper points to data sources not used widely yet.

There is a wealth of studies utilising remote sensing data and urban area classification approaches (Bhatta 2010; Patino and Duque 2013). Multi-temporal and time-series analyses have increasingly been applied in this area of urban and landuse mapping (Acevedo and Masuoka 1997; Li et al. 2018), or peri-urban growth (Shaw and Das 2018). Mapping transformation using remote sensing increasingly starts applying multi-spatial-resolution change detection (Zhang et al. 2016). However, many approaches in remote sensing studies focus on the technical advancements and are less applied for the operational mapping of urban transformation yet. And while urban growth studies are common (Bagan and Yamagata 2012; Masek et al. 2000; Song et al. 2016), fewer studies combine it with a spatial detection of exposure to natural hazards, especially over a range over more than 20-30 years in comparison. Even fewer studies have used satellite data before the 1970s, such as the declassified satellite data of the USA (Day et al. 1998). The USA has disclosed declassified former espionage imagery from the 1960s onwards that are hardly used for risk assessments so far (Fekete 2020). Declassified satellite data from the CORONA, GAMBIT or HEXAGON series have been applied rather selectively and not very often yet, to fields such as archaeology (Ur 2003), generation of digital elevation models (Altmaier and Kany 2002), glacier monitoring (Bolch et al. 2008; Narama et al. 2010), land-use (Tappan et al. 2000) or urban growth (Masek, et al. 2000; Stewart et al. 2004; Cecchini et al. 2019; Hepcan et al. 2013). 
There is an increasing demand for multi-modal, multi-spectral and multi-temporal remote sensing approaches (Brito and Quintanilha 2012; Qiming 2011; Stiller et al. 2021), and making use of a combination of aerial and satellite images can offer opportunities for that.

Aerial imagery and old declassified former espionage reconnaissance satellite imagery are major data sources to capture previous land cover back to the 1940s. Kenya has been covered by UK Royal Airforce aerial imagery campaigns due to the former colonial history. Access to such data is still restricted; it is on data servers not known much outside remote sensing communities. A lot of this data is open access, but sometimes, fees have to be paid, and although they are relatively low, it can still mean a restriction for researchers or local institutions. Another data access challenge is finding hazard data. This is the case for industrialised countries as well as for many other countries too.

Geospatial assessments are used in Kenya for monitoring land-use change or property rights (Koeva et al. 2017). Aerial imagery is also used for monitoring the sustainable development of agriculture (Ekbom et al. 2001). Challenges in defining urban boundaries and overestimating urban areas by single criteria such as population density are analysed using aerial imagery (Potts 2017). Hazards analysed using aerial images cover many hazards, including erosion and contamination, but also deal with lake basin (Khan et al. 2011; Habib et al. 2009) or riverine floods (Olang and Fürst 2011), flash floods (Hoedjes et al. 2014), rainfall variability (Gamoyo et al. 2015) or vector-borne diseases concerning floods (Pope et al. 1992). The early warning seems to be a topic of special interest for the whole country (Hoedjes, et al. 2014) or the Tana river basin (Otieno et al. 2019). The Tana river is covered by some studies (Leauthaud et al. 2013). But other areas are covered much less (Annex A). Existing land-use change assessments do not use data earlier than the mid1970s when LANDSAT satellite imagery became used. For example, Nairobi has been analysed regarding land-use and land cover change for 1976-2000 (Mundia and Murayama 2010). However, systematic multi-temporal assessments of exposure of settlements to floods, droughts or other hazards have not been conducted yet, only urban growth or exposure mapping for single static time periods. But there is a great potential applying flood exposure mapping for the assessment of multiple risks related to floods, such as flood risk indices (Hategekimana et al. 2018), health risks (Okaka and Odhiambo 2019) or early warning (Otieno, et al. 2019).

Therefore, the objective of this paper is to expand existing land cover change assessments back to the 1940s using aerial imagery. This enables capturing urban growth outside the national capital, Nairobi, along urban rims and in expanding towns in Kenya. A transferrable mapping approach is demonstrated, and it is indicated which natural hazard data could be used to analyse urban growth into potential hazard zones over time. Natural hazards include river floods in this case, and exposure of settlement area to be flooded is the main focus here. Using heterogeneous remote sensing data from different satellite missions and with different sensors and resolutions, a temporal comparison is made possible that exceeds previous approaches. In addition, this approach can analyse data-poor areas and areas not covered yet by research on natural hazards and exposure, which may inspire similar research in other areas.

\section{Method}

Geospatial assessments are useful to cover large areas of land by one comparable data source. It needs to be coupled with ground-truthing and thereby often is used in combination with other modes of assessment, such as local field visits, statistical data or others. However, geospatial data provides another form of multimodal characterisation, which is the special issue's focus. This case is a multi-modal selection of greyscale aerial photos, satellite-based greyscale imagery, multi-spectral recent satellite data, statistical data, and on-the-ground photos and field visits. Geospatial data is beneficial for analysing changes over time, using the same data source, or in combination with other modes of satellite, aerial remote sensing, ground-based imagery or many other forms of data integrated into a geographic information system (GIS).

\subsection{Case study areas}


The case study areas were selected in a co-design approach with the local experts and co-authors in joint workshops in Kenya on Sept 5 2019, and online, 17 Feb 2021. The two areas have been selected for demonstrating and testing the data availability and GIS-assessment opportunities of a combination of old aerial, former satellite espionage and recent satellite and OSM data. One area is the peri-urban rim of Nairobi, the nation's capital and largest city (Fig. 1). The area selected in the North-East is where urban sprawl and growth occur to a great extent; it is Ruiru town in Nairobi East along the Thika Road. The other area selected also experiences urban growth, the city of Nyeri, located North of Nairobi, close to the Aberdare and Mt. Kenya mountain ranges. Both case study locations (Fig. 1) experience major urban growth but are prone to natural hazards such as floods and droughts.

\subsection{GIS Analysis}

The analysis is a GIS assessment using remote sensing data in combination with statistical data. QGIS is used as the GIS software since it is cost-free, open-source and enables the usage with different computer operating systems; so, it can be used by partners in Kenya and Germany and other countries, in teaching as well as in further research. The projection used is WGS84 UTM Zone $37 \mathrm{~N}$, so metric analyses can be conducted.

First, urban growth is analysed by change detection using aerial images from 1948, declassified CORONA mission (Day, et al. 1998), related data from 1967 and 1977 and Sentinel 2 data from 2020. The earliest available data and sufficient spatial resolution, coverage of the case study area and cloud coverage, and costs were selection criteria for the data (Table 1 provides details on remote sensing data ordered and used). The aerial images were ordered from the National Collection of Aerial Photography from the UK. The declassified CORONA, HEXAGON and GAMBIT mission satellite images were obtained from the USGS Earth Explorer portal; three images were already available for free download. One additional image had been ordered. The OSM and Sentinel-2 data were openly available on OSM and EOX platforms.

Table 1

Aerial and satellite imagery used for this study

\begin{tabular}{|lll|}
\hline City & Aerial imagery available and date & $\begin{array}{l}\text { Declassified satellite data available for download, high resolution, } \\
\text { without clouds, date }\end{array}$ \\
\hline $\begin{array}{l}\text { Nairobi; } \\
\text { Ruiru } \\
\text { town }\end{array}$ & $\begin{array}{l}\text { NCAP-000-000-206- } \\
\text { 605_Mukuyu_Central_Kenya.png }=\end{array}$ & $\begin{array}{l}\text { GAMBIT mission; KH-7, Declass 2: 19-AUG-1966_2-4 feet } \\
\text { resolution. Ordered on Feb 21, arrived Feb 26. Ruiru was not } \\
\text { Ruiru. 15-2-1948, scale 1:19.000 }\end{array}$ \\
& & $\begin{array}{l}\text { HEXAGON mission, KH-9, from 27-SEPT-1977, tile DZB1213- } \\
\text { 500215L008001_b, 20-30 feet resolution }\end{array}$ \\
\hline Nyeri & $\begin{array}{l}\text { NCAP: DOS_PLD_00008: PDF and tile } \\
\text { mosaic, resolution not useful }\end{array}$ & $\begin{array}{l}\text { CORONA mission, KH-4a, from 16-JAN-1967, DS1038- } \\
\text { 1025DA059, tile b and DS1038-1025DF060, medium resolution } \\
\text { (20-30 feet) }\end{array}$ \\
\hline
\end{tabular}

The aerial photos and CORONA satellite images were georectified based on OSM and Sentinel-2 data as base maps. Urban features were manually extracted and digitised from the 1948 aerial photos and the CORONA satellite images at a viewing scale of 1:2.500 to 1:5.000 in QGIS. Sentinel-2 data were digitised at spatial scales between 1:5000 and 1:10.000. To capture built-up areas, mainly houses were mapped since they were the easiest to identify by rectangular shapes as distinct urban areas. Houses are identified mainly by the rectangular shape of the roofs. In addition, roads and paved (/impervious/sealed) areas were mapped when connected to buildings but not gardens or other partly natural surfaces. Special care was taken along rivers to capture houses and urban features. Vegetation land cover was mapped especially for human-shaped irrigated land use when it was identifiable by rectangular features such as roads or borders to other vegetation.

For training purposes, $100 \times 100$ m grids were created. An urban area is defined when adjacent urban features cover an area of at least $100 \mathrm{~m}^{2}$. Roads were only mapped when directly connected to buildings, up to $100 \mathrm{~m}$ to the buildings. Open 
spaces within a city were mapped as urban when surrounded by a built-up area. Still, they were excluded from the are to be defined as 'exposed' to floods, when those open spaces consisted of vegetation and non-sealed surfaces close to a river within the city. The mapped areas were then compared to recent land cover data from Sentinel-2 and Open Street Map (OSM) data to capture urban growth and land-use change, but also in some cases to check the plausibility of urban features still existing at the same spot.

Flood hazard features were analysed using water areas and bodies, river course and other hydrological data available from different data providers (OSM, Regional Centre for Mapping of Resources for Development, SRTM, World Bank Data Catalogue, World Resources Institute). Since no flood hazard zonation maps were available and no DEM in sufficient resolution, we have estimated a buffer zone around rivers in areas with rather even topography, crossing the city quarter of Nairobi North-East and Ruiru according to the average width of wetlands in data we found. We also checked it against a visual interpretation based on Sentinel-2 data from 2020. Since the wetlands had a buffer around the river of around 150 $200 \mathrm{~m}$ in width in the case study area as measured in the data set, we have mapped flood exposed areas by the length of settlement perimeters within a $150 \mathrm{~m}$ buffer zone. $150 \mathrm{~m}$ have been selected to remain more on the cautious side of estimations. Since topography consists of relatively flat basins in this area, the approach can be used, but of course, is not precise.

\section{Results}

Both case study areas, in Nairobi North-East and Nyeri, exhibit massive urban growth and growth into flood exposed areas and erosion and mass movement risk.

\subsection{Nairobi - Ruiru}

The mapping of the aerial image from 1948, the CORONA satellite data from 1977 and the Sentinel-2 data from 2020 reveals massive urban growth in north-eastern Nairobi (Fig. 2). The growth between 1948 and 1977 already is significant. It has to be noted that some of the settlement areas from 1948 as mapped from the aerial photo have not been mapped on the 1977 CORONA satellite image since the resolution was coarser. While some of the features, such as rectangular shapes that could be houses also are visible on the 1977 CORONA image, they were not mapped when the signal was not clear enough to retain a consistent mapping approach.

The assessment in Nairobi reveals a massive urban growth, as well as a growth of built-up area into potentially flood hazard-exposed zones, too (Fig. 3). To estimate flood exposure, buffer zones were created at $150 \mathrm{~m}$ width und have been checked against the topography as derived from a $30 \mathrm{~m}$ resolution SRTM model, as well as against pre-existing wetland data sets (Fig. 4). The results show that the $10 \mathrm{~m}$ contour lines and computed slope degrees match the $150 \mathrm{~m}$ buffer very well. The terrain is rather even, and therefore, buffers extend to both sides of the river course quite evenly.

Using GIS, the area sizes of the built-up areas are calculated, and the results show that for Ruiru, the built-up area had grown 20-fold from 1948 to 1977 and 10-fold from 1977 to 2020 (Table 2). At the same time, the potentially flood exposed area had grown 7 times from 1948 to 1977 and 3 times from 1977 to 2020 . The analysis also reveals that Ruiru had grown much more than the adjacent South-Eastern part of the outskirts of Nairobi between 1977 to 2020. And the flood exposure of Ruiru had grown even much more by comparison to the built-up area. The growth rate of Nyeri between 1967 to 2020 is quite comparable to the area analysed in Nairobi. However, since satellite data with sufficient resolution was not available from the same years, a direct comparison is not possible; it only can indicate similarities. Flood exposure also has increased in Nyeri, as the perimeter of the built-up area also has grown along the river Chanya. 
Table 2

Area sizes and growth as calculated from the aerial and satellite images

\begin{tabular}{|c|c|c|c|c|c|c|c|c|c|c|}
\hline $\begin{array}{l}\text { City } \\
\text { area }\end{array}$ & $\begin{array}{l}\text { Area } \\
\text { in } \\
1948 \\
\text { in } \\
\text { km2 }\end{array}$ & $\begin{array}{l}\text { Area } \\
1967 \\
\text { or } \\
1977 \\
\text { in } \\
\text { km2 }\end{array}$ & $\begin{array}{l}\text { Area } \\
2020 \\
\text { in } \\
\text { km2 }\end{array}$ & $\begin{array}{l}\text { Area } \\
\text { growth } \\
\text { rate } \\
1948- \\
1977\end{array}$ & $\begin{array}{l}\text { Area } \\
\text { growth } \\
\text { rate } \\
1977- \\
2020\end{array}$ & $\begin{array}{l}\text { Flood } \\
\text { exposure } \\
\text { length in } \\
\text { km } 1948\end{array}$ & $\begin{array}{l}\text { Flood } \\
\text { exposure } \\
\text { length in } \\
\text { km, } \\
1967 / \\
1977\end{array}$ & $\begin{array}{l}\text { Flood } \\
\text { exposure } \\
\text { length } \\
2020\end{array}$ & $\begin{array}{l}\text { Flood } \\
\text { exposure } \\
\text { growth } \\
1948- \\
1977\end{array}$ & $\begin{array}{l}\text { Flood } \\
\text { exposure } \\
\text { growth } \\
1977- \\
2020\end{array}$ \\
\hline $\begin{array}{l}\text { Ruiru } \\
\text { subset } \\
\text { area } \\
\text { (1948 } \\
\text { image } \\
\text { extent) }\end{array}$ & 0.016 & 0.349 & 3.783 & 21.998 & 10.845 & 0.500 & 3.600 & 14.000 & 7.200 & 3.889 \\
\hline $\begin{array}{l}\text { Nairobi- } \\
\text { NE } \\
\text { corner } \\
\text { (grey in } \\
\text { the } \\
\text { map) }\end{array}$ & & 0.349 & 3.783 & & 10.845 & & 3.600 & 14.000 & & 3.889 \\
\hline $\begin{array}{l}\text { Ruiru } \\
\text { (red on } \\
\text { map) }\end{array}$ & & 0.420 & 9.879 & & 23.496 & & 0.500 & 62.500 & & 125.000 \\
\hline Nyeri & & 0.151 & 1.618 & & 10.693 & & 0.500 & 5.500 & & 11.000 \\
\hline
\end{tabular}

Land-use changes are also observable within the Ruiru area as well as in Nyeri. In Ruiru, some areas had already been visibly transformed from natural environments to agricultural usage (Fig. 5). Interestingly, many areas that were used intensively in 1948 (orange borders on the map) were not used in the same way in 1977. In 1948, the signature of the aerial image revealed darker colours and regular shapes of both roads crossing it and regular parallel linear structures as common for crops. In 1977, these areas revealed a speckled and heterogeneous reflection with lighter and mixed greyscales. On the other hand, some areas were intensively used in 1977, which had not been used in this way in 1948 (red borders on the map). Some other areas had been used both in 1948 and 1977, presumably for agriculture (not mapped).

These land-use changes of some areas are important for mapping urban growth, too, since they show the landscape before settlement. In the southern part of the aerial image, one larger area is mapped (Fig. 6). It can be important to monitor such previous land usages for loss of biodiversity or for revealing settlements that have overgrown previous wetlands. It also shows up opportunities for drought monitoring and understanding long-term changes.

\subsection{Nyeri}

In Nyeri, a similar strong urban development took place between 1967 to 2020 (Fig. 7). Aerial images from before the 1960s could not be obtained, so no comparison to the 1940s was feasible. The location of Nyeri along the Chanya river indicates a potential flood risk, confirmed by local experts. Urban growth reveals an expansion of the potentially floodexposed built-up areas. Of course, local topography must be observed, which is quite steep in this terrain and means that a river flood may not affect both sides equally.

In Nyeri, the terrain is steeper than in Nairobi-Ruiru. However, the $150 \mathrm{~m}$ buffer zone still fits quite well to the general shape of the river Chanya valley, as derived from the STRM digital elevation model (DEM) (Fig. 8). But of course, due to the steep terrain, a much more accurate DEM data set and ground observation are necessary to evaluate the flood exposure risk. The SRTM data set exhibits some data processing flaws, as visible by large rectangular shapes of the slopes in the upper left part of Figure 8. The high degrees of inclination also point out landslides and erosion as natural hazards and related 
exposure risks. The circles in Figure 8 indicate areas for further observation on-ground, where bridges and buildings could be at risk of flooding or mass movement.

\section{Discussion}

The case study analysis reveals some potential usage of GIS in combination with remote sensing data for monitoring land-use change over several decades. Significantly, aerial imagery and older declassified satellite data can expand the time range covered.

\subsection{Data and methodology constraints}

It has become evident that many constraints exist, such as in spatial resolution and temporal availability. Satellite and aerial imagery missions in the 1980s and before were limited in temporal coverage, spatial resolution and also, not all areas have been covered in a country. Typically, larger urban areas or other areas of strategic military interest often become mapped primarily (Day, et al. 1998). For the case studies, it was more difficult obtaining images for Nyeri than for Nairobi. But even for Nairobi, older missions have mainly mapped the urban area at that time. At urban rims such as Ruiru, the availability of imagery was constrained. For example, the high-resolution image from 1964 did not cover these outskirts of Nairobi anymore.

The manual mapping may look a bit outdated given the development of semi-automated and automated machine learning unsupervised land-use classifications. However, since the aerial and satellite imagery is greyscaled and extracted from analogous film, manual interpretation and mapping still proved useful. Some attempts with the 2020 Sentinel-2 in using automated classifications of land-use or extraction of built-up areas revealed problems; the pattern of land-use and settlements in Kenya differs much from other areas in the USA, for example. This is due to different dense vegetation cover in Kenya and more speckled settlement types. Many smaller houses and shacks along roads and rural areas make it difficult to separate their signature from other features. Some huts in rural areas growing into peri-urban areas also have a rather rounded roof and stand intermixed with other features. Regular rectangular road layouts are often missing, and paved roads or open places usually make identifying built-up areas easier. The manual mapping approach proved to be more precise than earlier machine learning automated approaches compared with a publicly available data set (WRI 2007). But even up-to-date automatic extraction supported by artificial intelligence is constrained by data availability of Landsat data, ranging back globally to 1975, and its respective spatial resolution (Pesaresi et al. 2019; Schiavina, et al. 2019). The Global Human Settlement Layer provides data for Kenya for 1975, 1990, 2000 and 2015 in 250 m resolution, or combined in a multi-temporal data set up to $30 \mathrm{~m}$ (Florczyk et al. 2019; Freire et al. 2016). For 2017-2018, 10m spatial resolution is also available for the built environment, and $2 \mathrm{~m}$ for 2015 data. Comparing the machine learning approaches with manual mapping, the manually extracted results still are more precise in this spatial resolution (Fig. 9). But of course, the manual mapping is also constrained by original data resolution and mapping skills.

But of course, manual mapping and visual interpretation also know many challenges; for example, land-use change specification of vegetation types or identification of geomorphological features (Glass 2013). Multi-spectral imagery is much more apt to differentiate and identify vegetation types and urban features identification and separate built-up from other land-use types (Patino and Duque 2013; Wentz et al. 2014). The application of NDVI and density calculations was

analysed in this study for Nairobi using Sentinel-2 data but were not as precise and successful as in other areas such as the USA. This was due to the urban sprawl around Nairobi that provides a specific mix of vegetation and land use for farming within those areas, small huts and shacks and generally much fewer rectangular shapes of roads and urban layout than in the USA, for example. Remote sensing offers a range of further options for multi-spectral data or data in high spatial resolution, such as usage of thermal sensors (Voogt and Oke 2003), night-time light urban feature extraction (Wentz, et al. 2014; Zhao et al. 2019), object-based classification (Blaschke 2010; Kucharczyk et al. 2020), LiDAR data 
(Yan et al. 2015; Wedajo 2017), or radar data (Soergel 2010). This is promising for recent satellite data but has limitations when applied to greyscale older satellite images with often medium or rather coarse spatial resolution.

\subsection{Multimodal enrichment opportunities}

The presented GIS assessment can be extended from land-use change mapping to enrichment by additional data and interpretations. For example, when comparing with recent OSM data, features such as previous river beds that now have been overgrown by settlement areas could be added to OSM (Fig. 10).

Other options would be to add other sources of VGI, such as photos of locals after flood events or Twitter messages (Taylor 2016). Another option is to add community efforts in preparing flood response measures, as mapped in Kibera; removing garbage, widening rain channels, diverting floods with sandbags etc. (Nelson 2016). Another important area is adding vulnerability and resilience information. For example, about the informal settlements which cover many areas in Nairobi. Certain slums in the city centre have been covered by studies (Corburn and Karanja 2014), but peri-urban areas lack coverage so far. The potential of remote sensing data, however has been demonstrated to capture such informal settlements and could show an important method to cover such areas (Kraff et al. 2020; Taubenböck et al. 2018) where data availability and local accessibility often are a challenge, and ethical aspects must be observed, too. The same applies to covering other features of urban composition, too, such as central business districts that carry another type of economic risk (Taubenböck et al. 2013). But next to social vulnerability, dependency of urban areas from critical or baseline infrastructure is an upcoming topic, for example, as demanded by the United Nations (United Nations 2015). Urban populations depend on piped water, roads, food, and many other urban services that should be integrated into holistic risk assessments (Ledant 2013). But also, the natural environment needs to be included in such holistic risk assessments. For example, the ecosystem services, the risk, the value of nature-based solutions and investments into sustainable land use (Vogl et al. 2017). And while this article has shown applications to natural hazards only to flood hazards, it also indicated land-use change monitoring for other hazards such as droughts. It could also be applied to erosion and landslide risk.

\section{Conclusion}

The article demonstrates how urban growth into flood-prone areas can be mapped using aerial and satellite images over several decades. Since current international bodies and concepts such as the Sendai Framework demand more riskinformed decision making (United Nations 2015), the need for data, monitoring and data visualisation for decision-makers and the public have grown. Social inequalities, vulnerabilities and countries in the global South are a focus area due to natural hazard events and fewer resources to cope with damages and losses (Warner and Zakieldeen 2012; Wrathall et al. 2015). However, large areas, especially in the global South, are largely uncovered for even basic risk monitoring of urban growth or spatial exposure to common natural hazards such as river floods. Data scarcity adds only to the problem and underlines the knowledge gaps persisting (Osuteye, et al. 2017). Overall, this may point towards a distorted understanding of the risk of societies, where the disaster risk could be less known or understood in some countries less covered by data and respective risk assessments. Hitherto rather unexplored data and respective data repositories such as aerial imagery captured by former colonial governments or espionage reconnaissance missions could provide key innovations to expand the current limited understanding of the dynamic spatial development of risk. The article also shows caveats of limited availability and usefulness of old data when constrained by accessibility, spatial and spectral resolution. Visual mapping is time-consuming and limited to detecting certain types of natural hazards such as floods or landslides, droughts or wildfires. But it is a good starting point for risk mapping and expanding the application of remote sensing data.

Such temporal monitoring of exposure to natural hazards can help inform not only a static risk but also the dynamics of risk components such as urban expanse and settlement on former riverine areas over time. This can also help inform the current research trend on transformation in the context of climate change (Gibson, et al. 2016; Pelling, et al. 2015) about 
the opportunities existing for measuring changes using remote sensing data (Kraff, et al. 2020). Of course, many more aspects need to be added to capture risks, such as information about vulnerabilities, capabilities and resilience (Cutter et al. 2008). And for transformation, fundamental changes such as regime changes need to be added to capture what is currently understood as transformation (IPCC 2012; IPCC 2019; Solecki, et al. 2017). However, land-use change is a fundamental footprint of human activity and the result of many decisions taken in combination, such as economic, legal and environmental decisions. It is often difficult to capture how to avoid risks in context to on-going transformations and one example could be to better guide "build back better" programmes (Gibson, et al. 2016; Kennedy et al. 2008) on how to avoid reconstruction in areas where settlement have overgrown former river beds. Mapping spatial exposure transformation can therefore be understood as a tool helping to document and understand a larger transformation. In context to climate change, more documentation of the hazard trends and human interaction with natural hazard-prone areas is necessary, especially in countries underresearched and hampered by data scarcity.

\section{Declarations}

\section{Acknowledgements:}

The author is grateful to the DAAD, the German Academic Exchange Service, for funding mutual visits in Germany and Kenya, 2018-2020, within a project on a joint university of applied sciences. Gratitude is also expressed to the colleagues in the project and the joint discussions.

\section{Funding}

This work was supported by the DAAD, the German Academic Exchange Service, within the project "Learning by Co-Design

- Teaching is Research" 2018-2020, project-ID: 57526386.

\section{Competing Interests}

The author has no relevant financial or non-financial interests to disclose.

This research is not involving Human Participants and/or Animals.

\section{References}

1. Acevedo W, Masuoka P (1997) Time-series animation techniques for visualizing urban growth. Computers \& Geosciences.23 (4):423-435.

2. Altmaier A, Kany C (2002) Digital surface model generation from CORONA satellite images. ISPRS Journal of photogrammetry and remote sensing.56 (4):221-235.

3. Bagan H, Yamagata Y (2012) Landsat analysis of urban growth: How Tokyo became the world's largest megacity during the last 40years. Remote Sensing of Environment. 2012/12/01/;127 210-222.

4. Bhatta B (2010) Analysis of urban growth and sprawl from remote sensing data Heidelberg, Germany: Springer Science \& Business Media.

5. Birkmann J, Welle T, Solecki W, Lwasa S, Garschagen M (2016) Boost resilience of small and mid-sized cities. Nature.537 605-608.

6. Blaschke T (2010) Object based image analysis for remote sensing. ISPRS journal of photogrammetry and remote sensing.65 (1):2-16.

7. Bolch T, Buchroithner M, Pieczonka T, Kunert A (2008) Planimetric and volumetric glacier changes in the Khumbu Himal, Nepal, since 1962 using Corona, Landsat TM and ASTER data. Journal of Glaciology.54 (187):592-600. 
8. Brito P, Quintanilha J A literature review, 2001-2008, of classification methods and inner urban characteristics identified in multispectral remote sensing images. Proceedings of the Proceedings of the 4th GEOBIA, May 7-9, 2012 Rio de Janeiro - Brazil; 2012.

9. Cecchini M, Zambon I, Pontrandolfi A, Turco R, Colantoni A, Mavrakis A, Salvati L (2019) Urban sprawl and the 'olive'landscape: Sustainable land management for 'crisis' cities. GeoJournal.84 (1):237-255.

10. Corburn J, Karanja I (2014) Informal settlements and a relational view of health in Nairobi, Kenya: sanitation, gender and dignity. Health promotion international.31 (2):258-269.

11. Cutter SL, Barnes L, Berry M, Burton C, Evans E, Tate E, Webb J (2008) A place-based model for understanding community resilience. Global Environmental Change.18 598-606.

12. Day DA, Logsdon JM, Latell B (1998) Eye in the sky: the story of the CORONA spy satellites Washington DC: Smithsonian Institution.

13. Ekbom A, Knutsson P, Ovuka M (2001) Is sustainable development based on agriculture attainable in Kenya? A multidisciplinary case study of Murang'a district. Land Degradation \& Development.12 (5):435-447.

14. Fekete A (2020) CORONA High-Resolution Satellite and Aerial Imagery for Change Detection Assessment of Natural Hazard Risk and Urban Growth in El Alto/La Paz in Bolivia, Santiago de Chile, Yungay in Peru, Qazvin in Iran, and Mount St. Helens in the USA. Remote Sensing.12 (19):3246.

15. Florczyk AJ, Corbane C, Ehrlich D, Freire S, Kemper T, Maffenini L, Melchiorri M, Pesaresi M, Politis P, Schiavina M (2019) GHSL data package 2019. Luxembourg, EUR.29788 (10.2760):290498.

16. Freire S, MacManus K, Pesaresi M, Doxsey-Whitfield E, Mills J Development of new open and free multi-temporal global population grids at $250 \mathrm{~m}$ resolution; 2016.

17. Gamoyo M, Reason C, Obura D (2015) Rainfall variability over the East African coast. Theoretical and Applied Climatology. 2015/04/01;120 (1):311-322.

18. Gibson T, Pelling M, Ghosh A, Matyas D, Siddiqi A, Solecki W, Johnson L, Kenney C, Johnston D, Du Plessis R (2016) Pathways for transformation: Disaster risk management to enhance resilience to extreme events. Journal of Extreme Events.3 (01):1671002.

19. Glass CE (2013) Interpreting aerial photographs to identify natural hazards Amsterdam, The Netherlands: Elsevier.

20. Habib S, Policelli F, Irwin D, Korme T, Adler B, Hong Y Application of satellite observations to manage natural disasters in the Lake Victoria Basin. Proceedings of the 2009 IEEE International Geoscience and Remote Sensing Symposium; 2009 12-17 July 2009.

21. Hategekimana Y, Yu L, Nie Y, Zhu J, Liu F, Guo F (2018) Integration of multi-parametric fuzzy analytic hierarchy process and GIS along the UNESCO World Heritage: a flood hazard index, Mombasa County, Kenya. Natural Hazards.92 (2):1137-1153.

22. Hepcan S, Hepcan CC, Kilicaslan C, Ozkan MB, Kocan N (2013) Analyzing landscape change and urban sprawl in a Mediterranean coastal landscape: a case study from Izmir, Turkey. Journal of Coastal Research.29 (2):301-310.

23. Hoedjes JCB, Kooiman A, Maathuis BHP, Said MY, Becht R, Limo A, Mumo M, Nduhiu-Mathenge J, Shaka A, Su B (2014) A Conceptual Flash Flood Early Warning System for Africa, Based on Terrestrial Microwave Links and Flash Flood Guidance. ISPRS International Journal of Geo-Information.3 (2):584-598.

24. IPCC (2012) Managing the Risks of Extreme Events and Disasters to Advance Climate Change Adaptation. A Special Report of Working Groups I and II of the Intergovernmental Panel on Climate Change - IPCC [Field, C.B., V. Barros, T.F. Stocker, D. Qin, D.J. Dokken, K.L. Ebi, M.D. Mastrandrea, K.J. Mach, G.-K. Plattner, S.K. Allen, M. Tignor, and P.M. Midgley (eds.)], Cambridge, UK, and New York, NY, USA: Cambridge University Press.

25. IPCC (2019) Annex I: Glossary. In: IPCC Special Report on the Ocean and Cryosphere in a Changing Climate. In Press: H.-O. Pörtner, D.C. Roberts, V. Masson-Delmotte, P. Zhai, M. Tignor, E. Poloczanska, K. Mintenbeck, A. Alegría, M. 
Nicolai, A. Okem, J. Petzold, B. Rama, N.M. Weyer (eds.).

26. Kennedy J, Ashmore J, Babister E, Kelman I (2008) The meaning of 'build back better': evidence from post-tsunami Aceh and Sri Lanka. Journal of contingencies and crisis management.16 (1):24-36.

27. Khan SI, Hong Y, Wang J, Yilmaz KK, Gourley JJ, Adler RF, Brakenridge GR, Policelli F, Habib S, Irwin D (2011) Satellite Remote Sensing and Hydrologic Modeling for Flood Inundation Mapping in Lake Victoria Basin: Implications for Hydrologic Prediction in Ungauged Basins. IEEE Transactions on Geoscience and Remote Sensing.49 (1):85-95.

28. King D (2001) Uses and Limitations of Socioeconomic Indicators of Community Vulnerability to Natural Hazards: Data and Disasters in Northern Australia. Natural Hazards.24 147-156.

29. Koeva M, Bennett R, Gerke M, Crommelinck S, Stöcker C, Crompvoets J, Ho S, Schwering A, Chipofya M, Schultz C, et al. (2017) TOWARDS INNOVATIVE GEOSPATIAL TOOLS FOR FIT-FOR-PURPOSE LAND RIGHTS MAPPING. Int Arch Photogramm Remote Sens Spatial Inf Sci.XLII-2/W7 37-43.

30. Kraff NJ, Wurm M, Taubenböck H (2020) The dynamics of poor urban areas-analyzing morphologic transformations across the globe using Earth observation data. Cities.107 102905.

31. Kucharczyk M, Hay GJ, Ghaffarian S, Hugenholtz CH (2020) Geographic object-based image analysis: a primer and future directions. Remote Sensing.12 (12):2012.

32. Leauthaud C, Belaud G, Duvail S, Moussa R, Grünberger O, Albergel J (2013) Characterizing floods in the poorly gauged wetlands of the Tana River Delta, Kenya, using a water balance model and satellite data. Hydrol Earth Syst Sci.17 (8):3059-3075.

33. Ledant M (2013) Water in Nairobi: Unveiling inequalities and its causes. Les Cahiers d'Outre-Mer Revue de Géographie de Bordeaux.66 (263):335-348.

34. Li X, Zhou Y, Zhu Z, Liang L, Yu B, Cao W (2018) Mapping annual urban dynamics (1985-2015) using time series of Landsat data. Remote Sensing of Environment.216 674-683.

35. Masek J, Lindsay F, Goward S (2000) Dynamics of urban growth in the Washington DC metropolitan area, 1973-1996, from Landsat observations. International Journal of Remote Sensing. 21 (18):3473-3486.

36. Mundia CN, Murayama Y (2010) Modeling spatial processes of urban growth in African cities: A case study of Nairobi City. Urban Geography.31 (2):259-272.

37. Narama C, Kääb A, Duishonakunov M, Abdrakhmatov K (2010) Spatial variability of recent glacier area changes in the Tien Shan Mountains, Central Asia, using Corona ( 1970), Landsat ( 2000), and ALOS ( 2007) satellite data. Global and Planetary Change.71 (1-2):42-54.

38. Nelson KG. 2016. What Kenya's Biggest Slum Can Teach Us About Saving Cities From Floods. 7 Jan 2016. Available from https://ensia.com/features/what-kenyas-biggest-slum-can-teach-us-about-saving-cities-from-floods/; 21 Sept 2021

39. Okaka FO, Odhiambo BD (2019) Health vulnerability to flood-induced risks of households in flood-prone informal settlements in the Coastal City of Mombasa, Kenya. Natural Hazards. 99 (2):1007-1029.

40. Olang LO, Fürst J (2011) Effects of land cover change on flood peak discharges and runoff volumes: model estimates for the Nyando River Basin, Kenya. Hydrological Processes. 25 (1):80-89.

41. Osuteye E, Johnson C, Brown D (2017) The data gap: An analysis of data availability on disaster losses in subSaharan African cities. International journal of disaster risk reduction.26 24-33.

42. Otieno OM, Abdillahi HS, Wambui EM, Kiprono KS (2019) FLOOD IMPACT-BASED FORECASTING FOR EARLY WARNING AND EARLY ACTION IN TANA RIVER BASIN, KENYA. Int Arch Photogramm Remote Sens Spatial Inf Sci.XLII3/W8 293-300.

43. Patino JE, Duque JC (2013) A review of regional science applications of satellite remote sensing in urban settings. Computers, Environment and Urban Systems.37 1-17.

Page $11 / 16$ 
44. Pelling M, O’Brien K, Matyas D (2015) Adaptation and transformation. Climatic Change. 2015/11/01/;133 (1):113127.

45. Pesaresi M, Florczyk A, Schiavina M, Melchiorri M, Maffenini L (2019) GHS settlement grid, updated and refined regio model 2014 in application to ghs-built r2018a and ghs-pop r2019a, multitemporal (1975-1990-2000-2015) r2019a. European Commission, Joint Research Centre (JRC).

46. Pope KO, Sheffner EJ, Linthicum KJ, Bailey CL, Logan TM, Kasischke ES, Birney K, Njogu AR, Roberts CR (1992) Identification of central Kenyan Rift Valley Fever virus vector habitats with landsat TM and evaluation of their flooding status with airborne imaging radar. Remote Sensing of Environment. 1992/06/01/;40 (3):185-196.

47. Potts D (2017) Conflict and Collisions in Sub-Saharan African Urban Definitions: Interpreting Recent Urbanization Data From Kenya. World Development. 2017/09/01/;97 67-78.

48. Qiming Z (2011) Review on Change detection using multi-temporal remotely sensed imagery [J]. Geomatics World.9 (02):28-33.

49. Schiavina M, Freire S, MacManus K (2019) GHS population grid multitemporal $(1975,1990,2000,2015)$ R2019A. European Commission, Joint Research Centre (JRC) DOI: 10.2905.

50. Shaw R, Das A (2018) Identifying peri-urban growth in small and medium towns using GIS and remote sensing technique: A case study of English Bazar Urban Agglomeration, West Bengal, India. The Egyptian Journal of Remote Sensing and Space Science.21 (2):159-172.

51. Simonovic SP, Peck A (2013) Dynamic Resilience to Climate Change Caused Natural Disasters in Coastal Megacities Quantification Framework. British Journal of Environment and Climate Change.3 (3):378-401.

52. Soergel U (2010) Review of radar remote sensing on urban areas. In: Radar remote sensing of urban areas. Dordrecht, NL: Springer. p. 1-47.

53. Solecki W, Pelling M, Garschagen M (2017) Transitions between risk management regimes in cities. Ecology and Society.22 (2).

54. Song X-P, Sexton JO, Huang C, Channan S, Townshend JR (2016) Characterizing the magnitude, timing and duration of urban growth from time series of Landsat-based estimates of impervious cover. Remote Sensing of Environment. 2016/03/15/;175 1-13.

55. Stewart DJ, Yin Z-Y, Bullard SM, MacLachlan JT (2004) Assessing the spatial structure of urban and population growth in the Greater Cairo area, Egypt: a GIS and imagery analysis approach. Urban studies.41 (1):95-116.

56. Stiller D, Wurm M, Stark T, Angelo P, Stebner K, Dech S, Taubenböck H (2021) Spatial parameters for transportation: A multi-modal approach for modelling the urban spatial structure using deep learning and remote sensing. Journal of Transport and Land Use.14 (1):777-803.

57. Tappan GG, Hadj A, Wood EC, Lietzow RW (2000) Use of Argon, Corona, and Landsat imagery to assess 30 years of land resource changes in west-central Senegal. Photogrammetric engineering and remote sensing.66 (6):727-736.

58. Taubenböck H, Klotz M, Wurm M, Schmieder J, Wagner B, Wooster M, Esch T, Dech S (2013) Delineation of central business districts in mega city regions using remotely sensed data. Remote sensing of Environment.136 386-401.

59. Taubenböck H, Kraff NJ, Wurm M (2018) The morphology of the Arrival City-A global categorization based on literature surveys and remotely sensed data. Applied Geography.92 150-167.

60. Taylor F. 2016. Mapping the April 2016 Nairobi Flooding from Online Sources; Urbanark. Available from https://www.urbanark.org/Nairobi_flood_map_from_social_media; 20 Sept 2021

61. UN/HABITAT (2017) New Urban Agenda Quito, Ecuador: United Nations, Habitat III Secretariat.

62. United Nations (2015) Sendai Framework for Disaster Risk Reduction 2015 - 2030. United Nations Office for Disaster Risk Reduction: Geneva, Switzerland. 
63. Ur J (2003) CORONA satellite photography and ancient road networks: A northern Mesopotamian case study. Antiquity.77 (295):102-115.

64. Vogl AL, Bryant BP, Hunink JE, Wolny S, Apse C, Droogers $P$ (2017) Valuing investments in sustainable land management in the Upper Tana River basin, Kenya. Journal of Environmental Management.195 78-91.

65. Voogt JA, Oke TR (2003) Thermal remote sensing of urban climates. Remote sensing of environment.86 (3):370-384.

66. Warner K, Zakieldeen SA (2012) Loss and damage due to climate change. An overview of the UNFCCC negotiations.

67. Wedajo G (2017) LiDAR DEM Data for flood mapping and assessment; opportunities and challenges: A Review. J Remote Sens Gis.6 2015-2018.

68. Wentz EA, Anderson S, Fragkias M, Netzband M, Mesev V, Myint SW, Quattrochi D, Rahman A, Seto KC (2014) Supporting global environmental change research: A review of trends and knowledge gaps in urban remote sensing. Remote Sensing.6 (5):3879-3905.

69. Wrathall DJ, Oliver-Smith A, Fekete A, Gencer E, Reyes ML, Sakdapolrak P (2015) Problematising loss and damage. International Journal of Global Warming.8 (2):274-294.

70. WRI. 2007. Kenya GIS Data. ke_pop89Imb. In: World Resources Institute.

71. Yan WY, Shaker A, El-Ashmawy N (2015) Urban land cover classification using airborne LiDAR data: A review. Remote Sensing of Environment.158 295-310.

72. Zhang P, Gong M, Su L, Liu J, Li Z (2016) Change detection based on deep feature representation and mapping transformation for multi-spatial-resolution remote sensing images. ISPRS Journal of Photogrammetry and Remote Sensing.116 24-41.

73. Zhao M, Zhou Y, Li X, Cao W, He C, Yu B, Li X, Elvidge CD, Cheng W, Zhou C (2019) Applications of satellite remote sensing of nighttime light observations: Advances, challenges, and perspectives. Remote Sensing.11 (17):1971.

\section{Figures}

\section{Figure 1}

The selected case study cities, Nairobi and Nyeri, are within the most populated areas in Kenya (data: left tile: population density in 1989, data by WRI 2007, neighbouring countries by OSM 2021 data. Right tiles: GHSL population grid by (Schiavina et al. 2019), urban boundaries mapped using Sentinel-2 data)

\section{Figure 2}

Mapped area North-East of Nairobi, along Thika Road, at Ruiru town. Urban built-up area from 1948, 1977 and 2020. (Data: see Table 1 for the aerial image, CORONA and Sentinel-2 data)

\section{Figure 3}

Urban growth and 150 m buffer river zone at Nairobi Thika Road NE, at Ruiru town.

\section{Figure 4}


Contour lines in $10 \mathrm{~m}$ intervals and slope degrees (from SRTM data) overlayed on the $150 \mathrm{~m}$ buffer zone created

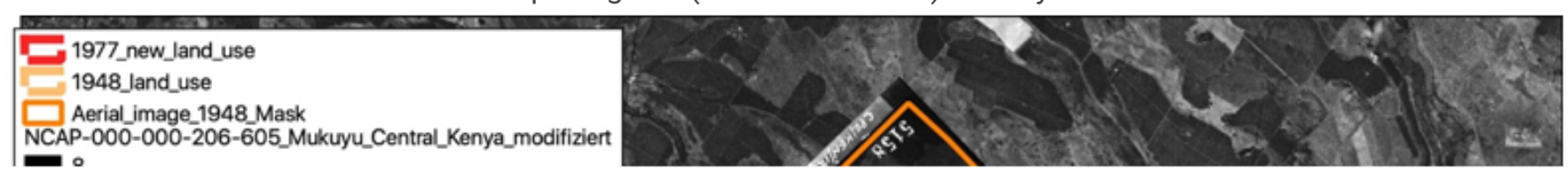

\section{Figure 5}

Land-use changes in Ruiru from 1948 to 1977. (Data: see Table 1 for the aerial image and CORONA data) 


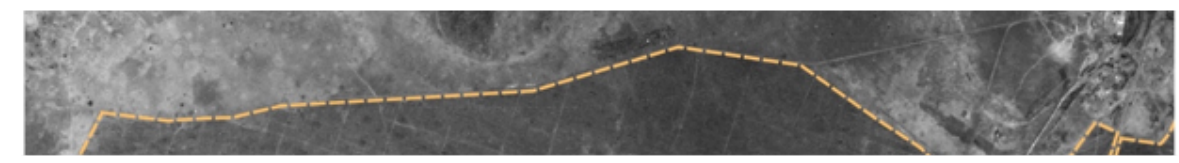

\section{Figure 6}

Development from intense agricultural use in 1948 to mixed-use in 1977 and the rather dense built-up area in 2020 in Ruiru. (Data: see Table 1 for the aerial image, CORONA and Sentinel-2 data)

\section{Figure 7}

Urban growth in Nyeri from 1967-2020

\section{Figure 8}

Urban boundaries of Nyeri in 2020 overlayed on digital elevation model (SRTM), with Chanya river 150m buffer zone. 


\section{Figure 9}

Manually mapped built-up areas in 2020 from Sentinel-2 data, as compared with the built-up area in 1989 (left; data by WRI 2007) and 1975 and 2015 (right; data by (Schiavina, et al. 2019)) extracted automatically by machine learning approaches

\section{Figure 10}

Identification of previous river beds (1977) within recent settlement areas (2020) in Nairobi Githurai (Data: CORONA image left and OSM data right)

\section{Supplementary Files}

This is a list of supplementary files associated with this preprint. Click to download.

- Annex.docx 